\title{
Wartime Romance
}

Chapters 1 and 2 center on songwriters and poets who participated in Sri Lankan movements that sought to politicize religion and language as symbols of Sri Lankan or Sinhalese identity. Sinhalese songwriters and poets fashioned their projects in relation or opposition to Western or Indian cultural influence. In this chapter I demonstrate that identity politics suddenly grew faint during World War II. During the war songwriters and poets grew weary of didacticism pertaining to religion and linguistic identity. Amid rapidly growing publishing and music industries, they turned toward romanticism to entertain the public.

When the Japanese attacked Pearl Harbor in December 1941, Sri Lankans feared the Japanese would also bomb the British naval bases in Colombo. ${ }^{1}$ Daily sirens announced citywide rehearsals to prepare for a similar strike. Protective bomb shelters and trenches were created throughout Colombo in case of an attack. The government ordered residents to place black paper over lamps in the evening to prevent enemy ships from locating heavily populated areas of the city.

Three months after the attack on Pearl Harbor, the Japanese navy launched the Easter Sunday Raid, an air attack against the British naval bases in Sri Lanka. They bombed Colombo and killed thirty-seven Sri Lankan civilians. In September the British armed forces transformed a variety of Sri Lankan institutions into military bases. The Royal Air Force used the radio station as their base, and the armed forces took over schools, such as S. Thomas' College in Mount Lavinia, Colombo. The city became populated with soldiers from England, France, and India. ${ }^{2}$

Given Sri Lanka's political alignment with the Allied powers and the arrival of Allied forces to Colombo from England, France, and India, it is not a coincidence that the new forms of Sinhala song and poetry, what I am calling "wartime 
romance," were indebted to works by famous English, French, and Indian poets and novelists. The Sinhalese poets and songwriters who drew on Indian or Western European ideas of romance likely sought to connect their writings, readers, and listeners to the imagined community of Allied nations.

As mentioned in chapter 1, in the nineteenth and early twentieth centuries, British colonists inculcated Indians and Sri Lankans with Christian and Victorian morals, which the British disguised as universal mores of civilized culture. Velcheru Narayana Rao argues that Telugu poets consequently began to view physical love in premodern Telugu literature as obscene. Sudipta Kaviraj asserts that British Victorian morals also influenced the Bangla poetry and song of Rabindranath Tagore, who shifted conceptions of love from a śringāra, or erotic notion, found in traditional Sanskrit aesthetics to a more Victorian idea of conjugal love. Karine Schomer suggests that the chāyāväd (romantic) Hindi poets of the 1920s and 1930s subsequently assimilated into their style the poetry of the English romantics and Tagore. The chāyāvād poets created a "new kind of [Hindi] love poetry, in which lovers were portrayed as soul mates who could open their hearts to each other, share a sense of wonder, and experience through their love a mutual growth of personality."3

By the 1940 s such trends also became evident in Sri Lanka. Major influences on song and poetry during this decade include the poetry of Tagore, nineteenthcentury English poetry, and fin de siècle French romance. Sinhala songs and poems of the 1940 os possessed a carefree quality that provided readers and listeners with experiences dissimilar from those afforded by the moralist songs and poems of the Arya-Sinhala (chapter 1) or Heḷ Havula songwriters and poets (chapter 2). Instead, the new romantic themes may have allowed young Sinhalese men and women to wistfully imagine a society free of caste-based marriages. Perhaps it also eased anxieties about perishing in an immanent Japanese air strike.

\section{TAGORE, ROMANCE, AND GRAMOPHONE SONG}

Chapter 1 discusses how the earliest Sinhala-language gramophone songs in Sri Lanka were recordings of nurthi songs, or songs that combined Buddhist revivalist themes with melodies from Indian (Hindi or Tamil) film songs. In the 1940 s the new major influence was that of Rabindranath Tagore. In Sinhala song the legacy of Tagore can be found in the gramophone songs of Ananda Samarakoon $(1911-62){ }^{4}$

Samarakoon had been working as a music teacher in 1934 when Tagore staged his opera Shapmochan (Curse redeemed) in Sri Lanka. At this time Samarakoon went by his Roman Catholic birth name, George Wilfred Samarakoon. Inspired by Tagore's opera, Samarakoon left for Bengal in 1936 to study music and art at Tagore's college of fine arts, Santiniketan. ${ }^{5}$ Samarakoon studied art with Nandalal Bose and 
music with Shanti Dev Ghosh. He returned to Sri Lanka after six months, converted from Roman Catholicism to Buddhism, and changed his first name to Ananda, a Sinhalese Buddhist name. ${ }^{6}$

One can only speculate about what caused Samarakoon to embrace Buddhism and change his name. Tagore's personal, intellectual, and artistic embrace of Hinduism perhaps led Samarakoon to want to disavow his Catholic namesake, which could have been said to represent Sri Lanka's colonial legacy. Maybe Samarakoon also felt a less Anglicized and more Sinhala name would help him become a singer-songwriter appreciated by the Sinhalese majority in Sri Lanka. Three additional influential Sinhalese composers of the 1940s changed their names in a similar fashion. In addition to Samarakoon, Baddeliyanage Joseph John adopted the name of Sunil Santha (chapter 2); W. D. Albert Perera modified his name to W.D. Amaradeva; and Eustace Reginald de Silva changed his name to Ediriweera (E. R.) Sarachchandra.

In 1939 Samarakoon signed a two-year contract with His Master's Voice (HMV) and made his first two gramophone recordings. The recordings were part of one hundred new Sri Lankan gramophone records produced through collaboration between HMV and Cargills, a powerful import and wholesale business. ${ }^{7} \mathrm{HMV}$ had become the largest recording company in the world. ${ }^{8}$ Samarakoon set himself apart in the local music industry as the only Sinhalese artist whose records HMV classified as a distinct genre known as kalātmaka gī (artistic song). ${ }^{9}$

Samarakoon stated that in the realm of song his true guru (teacher) was Tagore. ${ }^{10}$ It is thus not surprising that Samarakoon's two earliest recordings reveal the impact Tagore had on his compositions: Samarakoon composed new lyrics according to Tagore's melodies and the short and long mātrā (syllabic instants) in Tagore's song texts. Samarakoon thus created his earliest songs in the same way as his alut sindu predecessors (chapter 1). Sunil Ariyaratne discussed how this compositional practice tended to produce Sinhala songs with a strange mix of words. Example 3 indicates how Samarakoon set the lyrics of his song "Jana Säma Mana" (All the minds of the people) to the melody and short and long mātrā of Tagore's "Jana Gana Mana” (Thou art the ruler of the minds of all people, 1911), which became India's national anthem. Samarakoon also arranged the lyrics of his second song "Balanna Sohoyuriye" (Look, my sister) to the melody and short and long mātrā of Tagore's "Jodi Tor Dak Shune Keu Na Ase Tobe Ekla Cholo Re" (If nobody responds to your call then go alone, 1905). ${ }^{11}$

Although Samarakoon was under the spell of Tagore, he also began in 1939 to compose his own songs. ${ }^{12}$ His original songs were unique because he sang the song, wrote the lyrics, and arranged and composed the music. These tasks usually required three people. Readers of this chapter may think lightly of such an accomplishment. I thus must emphasize that in the early twentieth century most Sinhalese songwriters did not possess musical knowledge to compose original melodies deemed suitable 
EXAMPLE 3. Ananda Samarakoon's use of Tagore's melody and poetic rhythm.

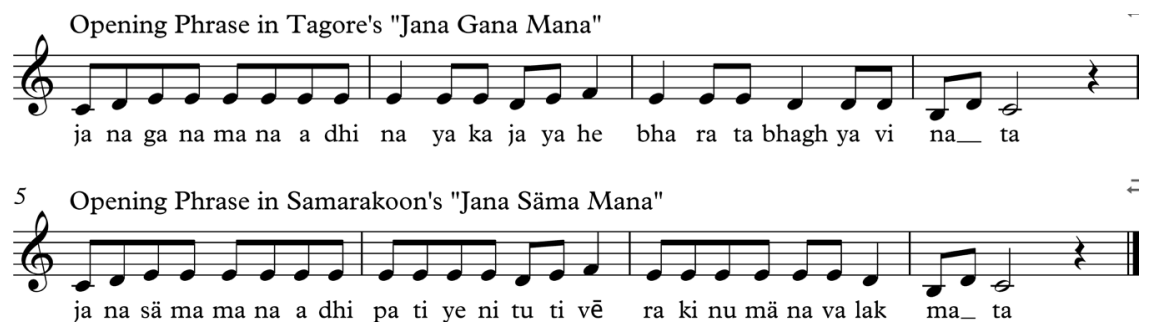

for gramophone songs. It was not a taken-for-granted skill. Ananda Samarakoon and Sunil Santha had to travel to North India to learn how to use Indian rāgas and instruments to create a two- or three-minute gramophone song. As discussed in chapter 1, John De Silva even paid Visvanath Lawjee to travel from western India to compose rāga-based melodies for De Silva’s nurthi theater productions.

In 1941 HMV released Samarakoon's "Enḍada Mänike" ("May I come, my gem?")-a song for which Samarakoon composed, arranged, and performed as the main vocalist. The song was a dialogue between a girl and a boy. Such "dialogue songs" forged links to the nurthi theater songs (see chapter 1) that had inspired the first gramophone recordings in Sri Lanka. Samarakoon may have thought that audiences accustomed to theater songs on record would prefer to purchase recordings that featured similar theater-style dialogues.

"Enḍada Mänike" was different, however, because of its focus on romance. Most gramophone songs at the time had texts that praised the Buddha or offered some form of advice. ${ }^{13}$ Let us consider the scene that Samarakoon portrayed in "Enḍada Mänike." Here, the Indian goddess Saraswati assumes the disguise of a young woman. Enchanted, a young man attempts to woo her. He invites her to come into the river to pluck flowers:

Boy: Mänike, may I come into the deep river to pluck kekatiya flowers?

The kekatiya flowers in bloom are so beautiful, beautiful, beautiful

Girl: Don't fatigue yourself, don't, don't, please, don't, don't, please, just stay on the riverbank

Boy: The bending kekatiya flowers are so beautiful, beautiful, beautiful ${ }^{14}$

The dialogue takes on a shade of eroticism when the girl's white dress becomes wet. Yet the song remains charming, almost as if it was meant for children to perform:

Boy: See, see, your white dress is getting wet from the waves Mänike's white dress is so beautiful, beautiful, beautiful

Girl: Now I'm all wet, now I'm all wet, now I'm all wet, fine, it's no problem

Boy: Mänike's white dress is so beautiful, beautiful, beautiful ${ }^{15}$ 
One cannot trace the melody of this song to works by Tagore, but the musical texture of "Enḍada Mänike" evoked the simple orchestrations of Tagore's Bangla songs. Samarakoon sang the vocal line above a constant drone played on a tanpura, and the only melodic accompaniment was a sitar that shadowed the vocal melody. The ensemble was rounded out with a tabla and tambourine. Further, Tagore's method of bringing folk sources into modern songs inspired Samarakoon, who made this remark in 1956: "Tagore . . . used folk poetry as a source [for modern song] in a way that did not compromise its [folk song's] natural traits. Tagore was influenced by Indian classical music but one can also hear in his music the qualities of Bangla folk poetry. ... Taking as our model [Tagore's] Bengali music, we can also produce a form of Sri Lankan popular song. To do so, we must also use folk poetry as our base." ${ }^{16}$ Samarakoon emphasized the importance of using Sinhala folk sources, yet in practice he seldom attempted to rework texts of Sinhala folk poems into modern songs. A folk quality in Samarakoon's songs, however, can be read in his use of colloquial Sinhala lexicon, which is a characteristic feature of jana kavi (folk poetry). ${ }^{17}$

"A change in poetic sensibility," Karine Schomer writes, "usually entails a change in diction as well." ${ }^{18}$ For Samarakoon, a shift in sensibility in Sinhala song from Buddhist edification to romantic love necessitated a change in lexicon from the literary to the colloquial. Generally speaking, the Sinhala language has two main varieties: the literary and the colloquial. The literary is customarily used for written materials, public speeches, and television and radio news reports. The colloquial is the everyday language of the Sinhalese people. Before "Endada Manike" was released, songwriters did not use the colloquial Sinhala adjective for "beautiful"-lassanayi-in gramophone songs. Songwriters favored more literary adjectives for beautiful like ramya, suram, manōhara, siriya, and sōbana. Perhaps the word lassanayi, with its colloquial tone, had never been appropriate because many of the older gramophone songs had Buddhist and thus sacred undertones. Samarakoon must have sensed that colloquial speech in secular love songs would make for a hit because in the first minute and ten seconds of "Enḍada Mänikē" he employed the word lassanayi twelve times.

Lassanayi was far from the only colloquial term in the song. Samarakoon utilized a variety of colloquial forms including the simple past, past-tense verbal adjective, and colloquial interjection. For instance, the boy sang, "oho lassanayi oho lassanayi oho lassanayi." The word oho is a spoken interjection that means "wow!" The girl told the boy, "Don't fatigue yourself, ane don't, ane, just stay on the river bank." $A n \bar{e}$ is another spoken interjection that here means "please!" Further, Samarakoon employed the colloquial past-tense verbal adjective in the phrase pipichcha kekatiya mal (kekatiya flowers that have blossomed) instead of the literary term, pipunu. And when the girl's dress becomes wet, Samarakoon described it with the colloquial simple-past term temichcha ("became wet") instead of the literary temunā.

Let us consider one final example emblematic of the shift in gramophone songs from didacticism to romance. After Samarakoon converted to Buddhism, he wrote 
what he considered his first Buddhist song, "Vilē Malak Pipilā" (A flower in the lake has blossomed) because it featured a dialogue about rebirth. ${ }^{19}$ Samarakoon stated that he felt inclined to write the song because he was studying Buddhist literature and reading debates about the subject of rebirth. ${ }^{20}$

Samarakoon may have described the composition as a Buddhist song, but one could also label the composition as a love song. The song opens with the same scenario found in "Enḍada Mänikē" (and in Sunil Santha’s song "Ōlu Pipīlä): a young boy hopes to pick a flower in the pond with the girl he loves. In Samarakoon's "Vile Malak Pipilä" the boy tells the girl that the time is suitable to pick flowers because today is Poya, the Buddhist holiday that occurs on a full-moon day. They can pick a lotus flower and bring it to the Buddhist temple for worship:

Boy: A beautiful flower has blossomed in the lake. Let's go my Gem to pick it. The man on the moon is peeping. Today is Poya my fair one, isn't it?21

Next, the girl expresses ideas about celibacy, ideas that revivalists like Ananda Rajakaruna (chapter 1) had advocated in poems like "Kumaribambasara":

Girl: Pick the flower and give it to me. I will offer it in worship to Lord Buddha.

My only wish is to be that pure flower.

Boy: Explain to me more about your wish.

Girl: My only wish is to be a flower in my next birth.

Boy: O my! Why do you think like this? What's the point of being a flower? Would it be so bad to be a princess shining in splendor?

Girl: A pure and beautiful [ramya] flower is a valuable object in this world. How can an impure human soul be greater than this? ${ }^{22}$

Rather than use the secular word for beautiful (lassanayi), Samarakoon chose the literary term (ramya) in the second-to-last line because the beauty the girl spoke of was related to chastity and Buddhist values. Samarakoon, however, departed from purely edificatory concerns when he alluded to the boy's erotic wish with this passage in the song: "In my next birth may I become the honeybee that drinks the flower's pollen." The fact that the boy, in the face of a moral message, unabashedly communicated his sexual desires exemplifies the shift from didacticism to romance that took place in Sinhala gramophone song in the early 1940 .

\section{TAGORE, ROMANCE, AND POETRY}

The Sinhalese poets who rose to prominence during World War II are known as the "second-generation Colombo poets." Like Samarakoon, they grew weary of their predecessors' focus on Buddhism and edification. As Miniwan P. Tillakaratne argues, "Love finds a special place in the works of the Colombo poets of the forties. This tendency ... came about as a result of some of the poets' keenness to free 
themselves from the classicism of the first group of Colombo poets who held on to traditional Buddhist values to a great extent." ${ }^{23}$

The second-generation Colombo poets could be considered parallel with the Hindi chāyā $v \bar{a} d$ poets who rejected the didacticism of the previous generation in favor of the romanticism of the English romantics and Rabindranath Tagore. ${ }^{24}$ Consequently, the second-generation poets' depictions of love were often less related to the eroticism found in classical Sinhala or Sanskrit poetry and more along the lines of the romantic and sentimental type of love explored by the English romantics, Victorians, and Tagore. As Ranjini Obeyesekere explains, "Love poetry or poems evoking śrngāra rasa (erotic mood) were a well-known feature of classical Sinhalese poetry. However, romantic sentimental love between young people, prior to, or unrelated to marriage, hardly ever occurs in the ancient poetry. It is evident that romantic or sentimental love as distinct from the love between man and wife, or mistress or courtesan, occurs for the first time in early modern [second-generation] Sinhalese poetry and can be directly related to the influence of the 19th century romantic poets; perhaps too to the 19th century novel." ${ }^{25}$ Sudipta Kaviraj similarly describes Tagore's conception of love as a transition away from śrngāra rasa (erotic mood) to the modern prem, the Bangla-language term for a more emotional and romantic love: "In the historical transformation of the discourses of love, Rabindranath Tagore was a principal performer and his work constituted a principal site of the transition from one aesthetic structure to another. In convenient shorthand, this change can be simply designated as a change from śrngāra, conventionally translated as erotic love, to prem [emotional and romantic love]." ${ }^{26}$

Following Tagore's visits to the country in 1922, 1930, and 1934, Sinhala poets relished Tagore's English-language poetry books in wide circulation in Sri Lanka, such as Gitanjali (Song Offerings, 1912), Fruit Gathering (1916), and Stray Birds (1916) and Tagore's collection of stories, The Hungry Stones and Other Stories (1916). For instance, poet H. M. Kudaligama (1918-73) translated three entries from Stray Birds into Sinhala quatrains for the poem "Mataka Sațahan" (Memories), which appeared in Kudaligama's poetry collection $\bar{A}$ (She, 1948). ${ }^{27}$ Wimalaratna Kumaragama (1919-62) composed the poem Hapumali (1946), inspired by "The Home-Coming" in The Hungry Stones and Other Stories. ${ }^{28}$ Novelist Martin Wickramasinghe (1890-1976) wrote an article for the Dinamina newspaper about Tagore's visit to Sri Lanka in 1934. To prepare, Wickramasinghe read E. J. Thompson's Rabindranath Tagore: His Life and Works (1921) as well as Tagore's Fruit Gathering. ${ }^{29}$

Tagore's impact on Sinhala poetry began with P. B. Alwis Perera's (1917-66) first book of poetry, Uk Dandu Dunna (The sugarcane arrow, 1942). Uk Dandu Dunna could be said to have inaugurated second-generation Colombo poetry because of its unprecedented exploration of romance and sentimental love. Perera prefaced the poem with this introductory paragraph: "Love is a covetous feeling from heaven that rises in the human heart! The European poets entered into the garden of literature 
through nature's narrow path of love made of white sand. I too make such an effort with The Sugarcane Arrow. The great Bengali poet, Rabindranath Tagore, who glimpsed life in both a rainbow and a tiny flower bud, stated that the poet sees the whole world through such a narrow path. I have directly drawn upon Tagore's poetry to enliven the truth of this statement." ${ }^{30}$ It is difficult to determine precisely which of Tagore's poems Perera reworked to compose Uk Dandu Dunna. But one senses Tagore's influence in the wording of this introduction. Perera stated that Tagore "glimpsed life in both a rainbow and a tiny flower bud." Here, Perera might have been alluding to an idea found in Tagore's Stray Birds, number 117: "The grass blade is worthy of the great world where it grows." ${ }^{31}$ The image of a "narrow path of love" that leads into a garden could be viewed as reminiscent of Tagore's second entry in Lover's Gift (1918), which described the gift of love as an unfathomable garden. ${ }^{32}$

When Perera published Uk Dandu Dunna in 1942, Tagore's English works had not been translated into Sinhala. ${ }^{33}$ We know for certain that Perera had read in English Tagore's The Crescent Moon (1913), Fruit Gathering (1916), and Lover's Gift and Crossing (1918). From The Crescent Moon, Perera translated "The Beginning" and "The Champa Flower" into Sinhala poems, titled "Mavage Hangim" (Mother's feelings), and "Sapumala" (The sapumala flower). ${ }^{34}$ From Fruit Gathering Perera translated the work's thirty-seventh poem about the Buddhist monk Upagupta for his Sinhala poem "Abhicārikāva" (Prostitute). ${ }^{35}$ In 1961 Perera authored a long poem, Keyas, in memory of poet Sagara "Keyas" Palansuriya. In stanza 32, Perera parodied the fourth entry of Tagore's Lover's Gift, which stated, "She is near to my heart as the meadow flower to the earth:"

He [Sagara "Keyas" Palansuriya] is near to the heart of the Sinhalese Like the meadow flower is to the earth (v. 32) ${ }^{36}$

Although Perera mentioned Tagore's name in the introduction to Uk Dandu Dunna, the work cannot be wholly reduced to Tagore's influence. Uk Dandu Dunna commenced with stanzas that evoked the classical Sinhala and Sanskrit model of śrngāra rasa. Such a nod to classical poetry prompted one literary scholar to characterize the poem as a śrngārātmaka kāvya (Sanskrit-style erotic poem) about the eternal relationship between the poet and his lover. ${ }^{37}$ In classical Sanskrit poetry śrngāra rasa was the ädisasa (first literary mood) employed to depict the erotic relationship between Krishna and Radha. ${ }^{3}$

Perera began his poem with a scene that depicted the commencement of the spring season, which he endowed with a royal feminine presence. The fanfare of trumpet-like thunder and elephant-like rain clouds announced the arrival of spring:

The lightning and thunderbolt-trumpets summon

Elephant-clouds that drizzle gentle drops of rain

The gods become pleased listening

To the Spring Goddess sing songs (v. 1$)^{39}$ 
In this stanza and the following, Perera's template for composing poetry about love was strikingly parallel with the classical śrngāra idiom found in traditional Sanskrit aesthetics, where the splendor of nature was often reminiscent of feminine beauty..$^{40}$ Consider the second stanza:

Her ponds and lakes overflow with water

In her hair she has dunukē, kolom, and mango-leaf flowers

In her grasses grow new plants like precious blue-green stones

Her earth is like a queen that shines in splendor (v. 2$)^{41}$

To intensify the beauty of nature's water, flowers, and plants, Perera described them as feminine body parts of the Spring Goddess. He continued to explore classical Sanskrit aesthetics in the following stanzas that introduced the Sanskrit literary characters of Kāmadeva (the god of love) and his consort Rati (the goddess of erotic delight). When the sun sets, Kāmadeva and Rati began to crave sexual pleasure:

As the moon shrouds all with cool milky white light

Kāmadeva embraces his wife Rati as if she is a pot of honey

[They are] eager to make love in the range of hills perched

Above the blue gem-like plantain forest (v. 7$)^{42}$

Perera described Kāmadeva according to the standard iconography in Sanskritlanguage stories: Kāmadeva wielded a sugarcane bow with a bowstring made of honeybees. His arrows were decorated with five different types of flowers: jasmine, asōka, white and blue lotus, and mango-tree:

He fashions arrows from sugar cane,

Fastens strings made of honeybees onto the bow,

Tightens into a bundle arrows decorated with

Jasmine, asōka, white and blue lotus, and mango-tree flowers (v. 8) $)^{43}$

As one accustomed to Sanskrit literature about Kāmadeva and Rati might expect, the scenes with Kāmadeva and Rati bristled with eroticism. When Rati galloped forward on her horse, for instance, the reader sensed that it was a symbol for the rush of lust.

Rati mounts the back of the wind-horse.

The ornaments on her thin waist tinkle

When she makes the horse gallop

Forward with her two spurs (v. 11) ${ }^{44}$

Given such classical imagery, where does one discern Tagore's influence? As discussed earlier, Kaviraj describes Tagore's conception of love as a shift away from śrngāra rasa to the modern prem, the Bangla-language term for a more emotional and romantic love. (In Sinhala the Sanskrit and Bengali term prem becomes 
prēma, prēmaya, or pema.) Although the beginning of the poem articulated śrngāra rasa, later passages in Uk Dandu Dunna featured a prem-type of romantic love that Perera likely found in the writings of Tagore. Critics of the poem may have sensed this because they emphasized the way in which Uk Dandu Dunna was about feelings (hängim). When describing the poem, Martin Wickramasinghe wrote, "P. B. Alwis Perera's Uk Dandu Dunna is a panegyric (varnanātmaka kāvyayaki) inspired by Rabindranath Tagore. To awaken feelings [in the reader] Perera praises women and love." Likewise, literary scholar Wasantha Atukorale described Uk Dandu Dunna as "a mixture of feelings that flow from one's heart when happy from love and beauty." 45

Such emotions begin to flow once Perera departed from the Sanskrit aesthetic model of śrngāra rasa to introduce a first-person narrator. In stanza 15 the speaker becomes the target of Kāmadeva's flower-arrow:

While Rati's sweet words flow like a river

Kāmadeva stings me with an asōka flower-arrow

And arrows decorated with jasmine and blue lotus flowers.

I'm hurt from these arrow-flowers, poisonous like the stingers of wasps (v. 15$)^{46}$

Stung by cupid's arrows, the narrator is overwhelmed with emotion. He proclaims that his lover's eternal beauty resides in nature's clouds, flowers, and rivers:

The eternal beauty possessed by my girlfriend's body

Resides within the cloud-paintings that float in heaven,

The trees and creepers, twigs and sprouts, and flowers in the month of navam

[And within] the river and ponds that praise my prosperous poetry (v. 19) $)^{47}$

He praises her smile, which he compares to the golden rays of the sun that dispel the dark:

My girlfriend's smile is like the

Sun that destroys the darkness,

Pours out the golden morning rays,

And spreads the morning beams in the paddy fields (v. 25) ${ }^{48}$

He later asks his lover these sentimental questions:

Sweetheart, where did you get this divine taste on your red lips?

Is it from the bee honey that was collected by bee stingers?

Is it from the aroma of the blossomed wild flowers?

Is it from cold dewdrops that fall on the flowers and become the nectar of heaven? (v. 189) $)^{49}$ 
To say Uk Danḍ Dunna was a mixture of only classical śrngāra rasa and modern prema would, however, miss two additional characteristics-clichés and bawdiness - which marked a decisive break with Tagore's poetry. Regarding the clichés, one literary scholar argued that the poem suffered from bolañda prēmaya (puerile or childish love) because of its monotonous clichés. Such hackneyed language was most pronounced in Perera's excessive use of terms of endearment, terms that literary scholar Ariya Rajakaruna described as susum pada, or "sighing words." Rajakaruna went as far as to list sixty-nine of these terms of endearment, such as: "Love gem; lover; pretty girl; gem; princess; sweetheart; my lovely; sweety; queen; my fountain; my moon dust; my rose; and my life." ${ }^{\circ}$ Consider, for example, the nearly comical terms of endearment that commenced stanza 255:

O fair skinned sweety! My milk droplet! My aromatic lump! (v. 255) ${ }^{51}$

Further, although Tagore subordinated sexual attraction to emotional companionship, Perera did not shy away from describing the feminine body. Perera compared his beloved's pinky finger to a pencil:

Your small pinky is like a pencil (v. 93) 52

He equated her breasts to rice-paper Japanese balloons:

When [I see] people who turn around after seeing my lover's breasts

I can somehow create a new metaphor:

Are her breasts not like a couple of Japanese balloons

Full of air and about to burst? (v. 95) ${ }^{53}$

And he described his lover's broad thighs as jackfruit:

Nicely matured broad thighs like a jackfruit (v. 99) ${ }^{54}$

Perera's attitude communicated to the new generation of Sinhalese poets that Sinhala poetry could also be a lighthearted medium to express sexual desire and romance, topics that had been taboo for the first generation of Colombo poets and the Hela Havula poets. Before Perera published Uk Dandu Dunna, moral and nationalist stakes were high in Sinhala poetry. As demonstrated in chapters 1 and 2, the Arya-Sinhala and Hela Havula poets used poetry as an ideological platform to campaign for the issues at the heart of their respective movements. In Perera's Uk Dandu Dunna, poetry was now a marketable medium for a popular pastime.

\section{FIN DE SIÈCLE FRENCH ROMANCE AND MIMANA PREMATHILAKA}

During World War II late nineteenth-century French romantic novels translated into English were available to the Sinhalese reading public. Consider this excerpt from an autobiography of the Sinhalese novelist Martin Wickramasinghe: 
When the British army landed in Sri Lanka during the Second World War the Sri Lankan government informed the managers of several secondary schools that they would have to handover the schools temporarily to the British armed forces. These school buildings became the bases of the British army. ... One day, my friend Victor Karunaratna came to meet me and brought two sergeants who were temporarily staying at S. Thomas' College.

"They have no books to read," Victor said, "I told them that I'll request a book or two from Wickramasinghe. What we want are two erotic books to read for pleasure."

"I don't have books like that but I can give you a real erotic story. It is not an easy read though."

Karunaratna was familiar with Guy de Maupassant's erotic literature. I gave him [an English translation of] Anatole France's The Red Lily [1894]. It tells a story about a women and her paramour. When it was published, one critic wrote, "It is unfortunate that such an elderly and erudite scholar such as Anatole France would write such a lusty book." ${ }^{55}$

Wickramasinghe's friend and his two companions from the British army wanted to read something entertaining to take their minds off of the war. In Wickramasinghe's mind, the obvious solution was the nineteenth-century French novel The Red Lily (Le Lys rouge). It told a story about a passionate liaison between married countess Thérèse Martin-Bellème and sculptor Jacques Dechartre. The liaison turned sour when Martin-Bellème's former lover Robert Le Ménil became abusive and started to stalk the countess.

Throughout the 1940s and early 1950 s poet Mimana Premathilaka (1918-65) published six works of Sinhala poetry that focused on the passions of romance. Some of these poems were graphic for their time, such as the long poems Ádaraya (Love, 1945), Anangayā (The Cupid, n.d.), Rati Sāgaraya (Ocean of lust, n.d.), as well as a small collection of poems titled $\bar{A} t$ Viu Prēmaya (The love that drifted away, n.d.). Premathilaka would later publish Pem Mānik (Love gems, 1952), as well as Sinhala translations of E. Powys Mathers's Coloured Stars: Fifty Asiatic Love Lyrics (1918) and Guy de Maupassant's "An Honest Deal," which Premathilaka titled Ananga Damanya (Controlling the Cupid, 1949).56 "An Honest Deal" is about a student who becomes obsessed with a prostitute-turned-actress. He follows her carriage home from the theater and lies outside of her house on the stone steps. She makes an "honest deal" with him: he can sleep with her one night. Then, he can no longer stalk her.

If Premathilaka translated Maupassant's short story, and if other French romance novels like Anatole's France's The Red Lily were available to Sinhalese intellectuals, one can speculate that the ecstasies and perils of passion in such literature made an impact on Premathilaka's romantic poems. Consider, for example, Premathilaka's pronouncement that prefaced the poem Ádaraya: "This is not a poem written to teach young girls and boys about the objective of love or the erotic mood [śrngāra rasaya]. I have written this to show how the love of a 
girl is filled with more lust than the love of a boy." ${ }^{\prime 7}$ In his preface to the poem, Premathilaka explained how the female character of the poem craved only sexual pleasure and had no use for emotional love: "The girl's goal is only to reach the summit of pleasure. One day she befriends another boy in a garden and forgets her lover.... She does not remember her previous lover at all except when she becomes pregnant from her paramour." ${ }^{38}$ Meanwhile, her first boyfriend wanted something more than lust: "It was not because of a craving for lust that her first boyfriend loved her." ${ }^{59}$

What shall we make of Premathilaka's statements and portrayals? In Anatole's France's The Red Lily the character Jacques Decharte, who was a surrogate for the ideas of France himself, propounds a similar idea that a woman is by nature more inclined to sleep with men, while men are more inclined to want to remain with one woman:

[Decharte:]

[Thérèse Martin-Bellème:]

[Decharte:]
"A woman cannot be jealous in the same manner as a man, nor feel what makes us suffer."

"I do not know that. Why can not she?"

"Why? Because there is not in the blood, in the flesh of a woman that absurd and generous fury for ownership, that primitive instinct of which man has made a right. Man is the god who wants his mate to himself. Since time immemorial woman is accustomed to sharing men's love." 60

If Premathilaka found inspiration in such ideas, he seemed to further want to vilify "promiscuous" women, an objective that diverged from authors like France and Maupassant. Consider Premathilaka's preface to Rati Sāgaraya: "Many people who find fault with love poetry often see the faults of the poet rather than those of his characters. Yet a poet writes about events that regularly happen in the world. Therefore, the fault ought not to be ascribed to him but to society. One who reads this poem will find it worthwhile if they direct their minds not toward the author but the undisciplined feminine character named 'Millie,' who behaves like the daughter of Cupid, giving her body to two young men." ${ }^{61}$

Both Ādaraya and Rati Sāgaraya ended tragically to teach the reader that "lustful" women would ultimately suffer miserable deaths. When the unnamed girl in A daraya becomes pregnant with the child of her new lover, he abandons her. She desperately tries to bring back her first boyfriend. But it is of no use. As the girl's baby grows in her womb she becomes depressed and commits suicide. ${ }^{62}$ In Rati Sāgaraya Premathilaka may have aimed to explore the destructive effects of jealousy as found in The Red Lily: Millie has a boyfriend named Victor, who supports her and her mother. Yet she sleeps with two other boys, one whose name is Simon. One day Victor comes over to the house when Millie is on the bed with 
Simon. Simon hides under the bed with a knife. When Victor lies with Millie, Simon jumps out and murders both of them (vv. 77-78). Millie's mother comes home and dies from a heart attack (v. 79).

Another aspect of Premathilaka's works that diverged from fin de siècle French romance is the way he wrote clichéd stanzas in these poems to titillate heterosexual male readers. He may have done so with the intent to sell books. Consider the following risqué verse from $\bar{A}$ daraya, where he portrayed a young woman pleading with her boyfriend to satisfy her sexual desires:

O my master! You know of the immortal lake.

It lies near my hill-like thighs and is the source of my river of love.

So why will you not take pleasure in it?

Dive deep and be destroyed by my love! (v. 54) ${ }^{63}$

In verse 54 Premathilaka describes her vagina as an "immortal lake" (amara vila) and a river of love (pem gan̆ga) that ran by her hill-like thighs (kaňdu väni vațora). Like Thérèse Martin-Bellème in The Red Lily, the unnamed girl in Ädaraya cared only about sexual pleasure and did not hesitate to cheat on her lover with another man, an encounter that Premathilaka described in verse like this:

They look at each other with half smiles

Sitting together, she tries to get him to like her

Now the beak of the swan nudges the lotus buds

They are immersed in the pain of pleasure (v. 67)

They sigh as they finish making love

After their faces collide they become red

She hurts the young boy with her white teeth

And gives to him her lovely two breasts (v. 69) (4 $^{4}$

The poem Rati Sägaraya was also graphic for its time. It began with eight-stanzas devoted to a description of Millie's body. Consider the fourth stanza:

This immature girl says sweet words

That delight all the boys who come and go

She wears a short skirt

When the wind blows, her tasty area can be seen (v. 4$)^{65}$

The reader subsequently learns that Millie's father was killed in a truck accident (v. 9). Millie and her mother become destitute (v. 10). A man who makes a good living from the black market named Victor falls in love with Millie (v. 11). He makes Millie and her mother's "poverty disappear like the sun evaporates the dew" (v. 12). But one day a boy in the neighborhood comes over and threatens Millie: if she does 
not touch him, he will kill whoever walks into the house. Millie is attracted to his violent power:

Seeing this young man's power

She felt love for him, not fear.

In that moment they felt a great [surge of] lust.

She said this with a gentle smile:

"Why must you be so rough?

You don't have to force me.

If you never cuddle me, the taste of love is not enough.

Please drink the taste of love while sucking my lips" (vv. 16-17) ${ }^{66}$

Millie’s language becomes wilder:

"Let's be on the bed together

Consoling each other, body on body

If that isn't enough, we can go further to heaven

Not only today, but everyday" (v. 18)

"Why are you looking at the colors of my nipples?

Can the color be scratched away? It is like that every day.

If you squeeze my two breasts more

It is OK, I won't feel pain" (v. 22$)^{67}$

In Ariya Rajakaruna's well-known book of poetry criticism, Nūtana Sinhala Kāvyaya (Modern Sinhala poetry, 1962) Rajakaruna criticized Premathilaka for writing vulgar (aślīya) poetry in Ādaraya and Rati Sāgaraya. In Rajakaruna's judgment, Premathilaka had written $\bar{A}$ daraya and Rati Sāgaraya to sexually arouse the reader. Rajakaruna argued that Premathilaka had transformed the cultured erotic mood of the śrngāra rasa into something distasteful to appeal to the baser instincts of the common reader. ${ }^{68}$

\section{LOCALIZING VICTORIAN ROMANCE IN SUDŌ SUDU}

Another form of literature available to Sinhala poets during and before World War II was the poetry of the English romantics and their eighteenth-century predecessors. As mentioned earlier, the romantics' sentimental depictions of love differed from the kind of erotic love portrayed in classical Sinhala or Sanskrit poetry. The Sinhalese poets of the 1940 s became well acquainted with the romantics and Victorians because they studied in secondary school the works by Thomas Gray, Oliver Goldsmith, William Wordsworth, Percy Bysshe Shelley, John Keats, Samuel Taylor Coleridge, Lord Byron, and Alfred Tennyson. ${ }^{69}$ 
Take, for example, the English translations of Premathilaka. He translated Elizabethan, Victorian, and romantic English verse into Sinhala poetry. In 1942 he translated Thomas Gray's An Elegy in a Country Church Yard (1751) into the poem Sohon Bima (Cemetery) and Shakespeare's Venus and Adonis (c. 1592) into Yamunā. He published in 1946 the poem Deväni Ādaraya (The second love), a composition based heavily on the narrative of Shakespeare's Romeo and Juliet. Two years later Premathilaka adapted Oliver Goldsmith's The Deserted Village (1770) into the poem Pālugama (Deserted Village, 1948) and in 1949 published Kirihami, inspired by William Wordsworth's Michael (180o).

Victorian poetry became a popular springboard for a new conception of romance in Sinhala poetry in 1943 after Sagara "Keyas" Palansuriya (1910-61) published the poem Sudo Sudu (Sweet, fair one, 1943). It was a work of 136 quatrains. Palansuriya adapted the story for Sudō Sudu from Alfred Tennyson's Enoch Arden (1864), an English narrative poem in blank verse. Sudo Sudu was one of the most popular second-generation poems of the 1940s. Quite unlike the erotic overtones in Uk Dandu Dunna, the message of Sudō Sudu was "true love is selfless."

One of Palansuriya's main tasks in Sudō Sudu was to localize the British characters, places, and events in Enoch Arden. The three main characters in Enoch Arden were Annie Lee, who was the "prettiest little damsel in the port"; Philip Ray, the only child of a wealthy miller; and Enoch Arden, "a rough sailor's lad."7o Palansuriya transformed Annie Lee into a widower's daughter named Hīn Mänikē (lit. "Skinny Gem") (v. 3). Palansuriya also changed the miller's son into Ṭikiri Bạ̣ụ, the son of a wealthy rālahāmi, or village headman (v. 2). He remade the sailor's son into Adiri, the strong son of a farmer (v. 2)..$^{71}$ The poem focused on an innocent and mildly rivalrous love triangle that later becomes a more split-object love triangle because Hīn Mänikē is torn between her love for Adiri (who leaves to fight in World War II) and Țikiri Baṇda, who takes care of her when Adiri is assumed dead.

"New stories," Ronit Ricci maintains, "are often presented in localized form so that they seem less foreign." ${ }^{72}$ Palansuriya strove to make Enoch Arden accessible to the majority of the Sinhalese who lived in rural towns and villages in the 1940s. He did this by transforming Tennyson's narrative at the moments it seemed too distant from the context of Sri Lanka. Consider the beginning of both poems:

\section{Enoch Arden}

Beyond, red roofs about a narrow wharf

In cluster; then a moulder'd church; and higher

A long street climbs to one tall-tower'd mill;

And high in heaven behind it a gray down

With Danish barrows; and a hazelwood,

By autumn nutters haunted, flourishes

Green in a cuplike hollow of the down. (v. 1) 


\section{Sudō Sudu}

Katuroda village is in a rural setting

Fertile and prosperous with land and mud.

A scenic river runs through the village

The market is found on the border of the village (v. 1$)^{73}$

Ricci further suggests that one of the common strategies to localize a narrative is to relocate scenes within a local landscape. ${ }^{74}$ Tennyson described a port in England, but Palansuriya detailed a Sinhalese village with a river running through and a kada mandiya, or marketplace, that traditionally sat on the border.

Palansuriya also made the poem accessible to people in rural towns and villages by using colloquial terms from the Sinhala language. Land (goda) and mud (mada) are commonly spoken metonyms for chena and paddy fields, respectively. This pair of words (goda-mada) has a special status in spoken Sinhala as a yugala padayak (set of paired words). Yugala pada are pairs of words with like-phonemes that refer to two objects found in one place (hatti-mutti, pans and pots) or related activities (ihum-pihum, cooking and cleaning). ${ }^{75}$

Sudo Sudu closely followed the chronological order of events in Enoch Arden. As did Tennyson, Palansuriya introduced the three main characters (vv. 2-3), narrated how they played together as children (v. 4), and related one incident: when the children play house, the boys fight over the girl's hand in marriage. She tells them not to fight and naively explains she will be wife to both. In Sudō Sudu Hìn Mänikē says innocently in colloquial Sinhala: "Don't fight. I'll be wife to both. You two are mine, isn't it? Let's play. What's all this commotion?" (v. 8).$^{76}$

To make the romance suitable for the Sinhalese readers Palansuriya inserted a new scene into his poem: Adiri asks Hīn Mänikēs mother, Angohāmi, permission to marry her daughter. "The first and major localization [of new stories]," Ricci argues, "is achieved by the use of the familiar language and idiom, which immediately makes texts sound similar to that which is already known." 77 In this scene, Palansuriya employed colloquial dialogue to make the encounter in the village believable. When Adiri arrives to the house, Angohāmi greets him with the traditional greeting of “āyubōvan” (May you live long) (v. 22), and she says, "arumäkkēe” village slang for "It's sure been a while."

hari kalakin novä mē lamayā däkkē mokada lamayo ada mē aru mäkkē (v. 23)

[It's sure been a while since I've seen this child, no? Why child, tonight, after such a long time? $]^{78}$

In Enoch Arden tragedy strikes after Enoch breaks his limb and becomes bedridden. His wife gives birth to a third child, who is deathly ill. In Sudo Sudu Adiri contacts malaria (v. 37) and Hīn Mänikē gives birth to a blind child (v. 40). In both 
poems the families become destitute. In Enoch Arden Enoch receives an offer to work on a boat headed for China and leaves to support Annie and the children. The sick child dies, and Annie must bury the child without Enoch. In Sudo Sudu Adiri boards a ship to fight in World War II, and Hīn Mänikē devotes her life to her blind son. Hīn Mänikē receives a letter posted from Singapore saying that Adiri was shot and had his hand cut off (v. 52). ${ }^{79}$ The reference to Singapore likely alludes to the fall of Singapore to the Japanese army in 1942, often considered the British forces' worst defeat in World War II. Soon after, Hīn Mänikē receives no more letters from Adiri. Despite his absence, Hīn Mänikēs love for her husband never wanes:

No more letters arrive after some time.

She does not know what happened to him.

[Yet] like a full moon that rises each Poya day

Her love for him is certain (v. 54) ${ }^{80}$

The final two sections in Sudō Sudu correspond to events in Enoch Arden. In Enoch Arden Philip Ray comes to the rescue to support Annie Lee. His love for her has not changed, so he cannot bear to see her suffer. He asks her to marry him, but she believes her husband will return. She asks him to wait for a year, then a month, and finally relents when she becomes convinced that her husband is dead. They marry and have children. The same scenario occurs between Țikiri Banḍa and Hìn Mänikē (vv. 56-117), except Palansuriya interjects a tear-jerking scene when Hīn Mänikēss blind son asks her to explain to him the concept of color (vv. 103-9) ${ }^{8}{ }^{8}$

The romantic melodrama reaches its climax when Enoch Arden/Adiri returns to the village unrecognized. He has survived a shipwreck and lived ten years alone on an island. In both poems he goes home and through the window sees his wife, content with her new family. In this moment, he expresses selfless love for her because he cannot bring himself to disrupt her now happy life. On his deathbed, he asks the housekeeper to explain his plight to his wife so that she knows how much he loved her. Enoch Arden ends with a funeral of the "brave heroic man" attended by the whole village. In Sudō Sudu Hīn Mänikē, Ṭikiri Bạ̣da, and their blind son are seen by the villagers every day lighting a lamp at Adiri's tombstone, which is in the corner of the garden of Tikiri Banḍa's valavva, or ancestral home (v. 136). $.^{82} \mathrm{Al}-$ though literary critic Ariya Rajakaruna credited Palansuriya's Sudō Sudu for its innovative use of colloquial language, Rajakaruna also criticized Palansuriya's conclusion because it was more British Protestant than Sinhalese Buddhist: Sinhalese Buddhist villagers do not offer flowers at cemeteries for their deceased relatives. ${ }^{83}$

I have shown in the three chapters of part 1 how songwriters and poets in the colonial era aimed to produce works that would contribute to Arya-Sinhala nationalism, Hela-Sinhala nationalism, or wartime romanticism, respectively. In part 2 I turn to the postcolonial period and inquire into the ways Sinhala song 
and poetry of the 1950 s and 1960s differed thematically, aesthetically, and politically from the colonial-era trends. Momentous political, societal, and institutional changes marked the 1950 s and 1960s. How did these configurations factor into the production of new songs and poetry? When songwriters and poets strove to create works that were artistically relevant, were their efforts characterized by support of, dissent against, or disinterest regarding the watershed moments that characterized the period? 
PART TWO

The Postcolonial Era 
